\title{
CHANGES IN WOMEN'S OCCUPATIONS AND OCCUPATIONAL MOBILITY OVER 25 YEARS
}

Shirley Dex, Kelly Ward and Heather Joshi

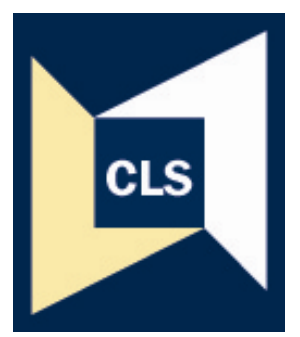

\section{Centre for Longitudinal Studies}

Institute of Education, University of London

Paper for

Women and Employment Survey

25th Anniversary Conference, Department of Trade and Industry

March 2006

(First presented in December 2005)

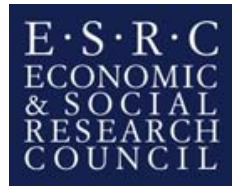




\section{Introduction}

The collection of employment histories in the Women and Employment Survey (WES) in 1980 started to break down the stereotypes still around in the 1970 s about women's careers. The tendency had been to think that a women's main role was as a mother, working at domestic tasks. Relatively few women were expected to have employment careers. The term 'career woman' was commonly used to describe the few, mainly thought to be single women, in professional occupations and viewed as freaks. What WES helped to show was that the majority (90\%) of women were returning to employment after childbirth and many were attached to their occupations in a way that could be described as having occupational careers, although they were not always able to return to their original occupation after an employment break for childbirth (Martin and Roberts, 1984; Dex, 1987). WES employment histories also showed that women had a sizeable amount of downward occupational mobility across the break from work for childbirth and this was more likely, the longer they stayed out of work at this point, and if they returned to a part-time job. In the 25 years since WES was collected and analysed much has changed in the UK labour market. It is time to take stock.

This paper will review the enormous changes in women's employment behaviour and occupational status that have occurred between 1980 and 2001. Cross-sectional data show the extent of this as there were far more women in top occupations in 2001 compared with 1980. The distribution of employed women through occupational categories in the 2001 Census compared with 1980 is much more like the distribution of employed men through occupation groups. By 2005, the position is likely to show even more equality. In this sense gender differences in occupational status have narrowed considerably over this 25 year period. What WES allowed us to do, largely for the first time, was examine the moving picture behind these snapshot statistics. This turned out to be vital for gaining a better understanding of where problems can arise and for formulating more appropriate policy responses.

At the time WES was carried out, in 1980, Britain had passed sex discrimination legislation (see Appendix table A1 for further details) in 1975, outlawing discrimination against women in employment on grounds of their sex or marital status. The UK had also introduced Statutory Maternity Leave from 1973, offering those qualifying the right to return to work after childbirth to the same job and same employer and offering some maternity pay. But clearly the eligibility conditions of having worked for 6 months with the same employer before pregnancy meant that many women were either ineligible or worked for employers who were not covered by the legislation. Relatively few of the women in WES would have benefited from these new laws and entitlements by 1980 .

In the past twenty five years, further legislation has been passed to strengthen the sex discrimination legislation and extend women's rights. These include successive extensions of the maternity leave period with a widening of its coverage to more and more women; successive increases in the paid maternity leave entitlement; the introduction of parental leave and paid paternity leave to allow fathers to have rights related to childbirth and parenting; and the Part-time Work Directive. This demanded employees working part time be given the same rights as full timers.

In this paper, we examine how women's occupational status and mobility have changed over the years since 1980. Women's and men's occupational mobility over their lifetime are important elements of their labour market position and rewards. It helps determine how equal or unequal men and women are in the labour market. 
Inequalities between men and women can occur by having varying rates of entering the same occupations and experiencing upward moves, downward moves or no movement or by entering different occupations at varying rates. Of course they can also be unequal in their pay by being paid directly at different rates for doing the same job. This paper is mainly concerned with vertical occupational mobility, which tracks individuals' movements between occupations over time using a hierarchy of occupations. WES was useful in documenting and quantifying the extent of women's downward occupational mobility over the first childbirth and across their whole life time up to 1980 . However, it only covered women. Twenty-five years later, we are able to draw some comparisons between women's and men's occupational mobility as well as to take the story forward about how women's occupational mobility has been changing within the context of better rights and entitlements.

\section{Plan of this paper}

In the rest of this paper we present a picture of change in women's occupations and occupational mobility between occupational categories since 1980. To some extent this has to be pieced together from the various data sets that are available whilst also manoeuvring carefully around the intervening changes to the occupational classifications and categories (Blackwell, 2001). This paper only goes part way to completing the picture since it does not yet include data from the most recent birth cohorts (Millennium Cohort Study) and it does not consider intra-occupational career mobility or wage mobility over the lifecourse.

In the next section we present a summary of the data sources used, followed by a discussion of how we intend to operationalize the measurement of vertical occupational mobility in this paper. From there, we go on to present, firstly, crosssectional occupation distributions to cover the period, showing the overall change in the snapshot picture of women's employment. Following this we compare the WES findings with other more recent data on women's occupational mobility at the point of childbirth, and with women's and men's experiences up to age 42. The paper documents changes in the timing of women's return to (paid) work after first childbirth and the extent of occupational change for women across their lifecourse and across childbirth. It will also examine whether the likelihood of downward mobility has changed over time for women in different positions in the labour market. 


\section{Earlier studies}

Occupational mobility has been studied extensively in a number of social science disciplines including sociology, management studies and economics. Within each discipline, there are further distinctions in the approaches adopted and the focus of interest. In sociology, studies have examined the determinants of individuals' occupational attainment (e.g. Blau and Duncan, 1967), the extent of intergenerational social mobility (e.g. Goldthorpe et al, 1987), careers and occupations as organisational or occupational careers, and occupational progression in particular professional occupations (see Dex, 1984). Economists have tended to focus on hourly wage rates and the determinants of individuals' wage growth mobility, focusing sometimes on highly qualified groups of men and women graduates in order to have more closely matched population groups for the comparisons (see Dolton and Silles, 2001). The labour market segmentation (LMS) theories also considered occupational immobility. Within these theories, internal labour markets or organisational careers are seen as being offered to the workers in the primary segment where the best high paid jobs were located. High job mobility is a feature of the secondary segment, where the worst and low paid high turnover jobs without career prospects were located. While having a heyday in the 1970 s such LMS theories declined in visibility thereafter but are still being debated (see recent review article by Leontaridi, 1998; Theodossiou, 1995; Steward and Swaffield, 1999).

The literature covering occupational mobility is, therefore, substantial and far too wide-ranging to include a thorough review in this paper. Both sociological and economic studies focused originally on men's occupational mobility. But increasingly papers have covered women's occupational mobility as well; for example sociological studies of social mobility (Payne and Abbotts, 1990), economists' analyses of wage growth (Booth and Francesconi, 1999), and labour market segmentation theories (Sousa-Poza, 2004).

Employment history data sets, of which WES was one, provided the opportunity to analyse occupational mobility. Moving up the occupational scale was shown to be linked to childlessness, and downward moves to taking up part-time jobs (Elias and Main, 1982; Martin and Roberts, 1984; Joshi, 1984; Stewart and Greenhalgh, 1984; Joshi and Newell, 1987; Dex, 1987). Jacobs (1999), using the Social Change and Economic Life (SCELI) data and the Cambridge scale analysed occupational mobility continuously over the lifetime of men and women, similar to Rosenfeld (1979) in the USA. Jacobs showed that there is considerable occupational mobility over men's lifetime, as measured by the Cambridge scale. The other findings were broadly the same as the earlier studies where being a childless woman or a man as well as being highly qualified helped achieve upward occupational mobility whereas being employed part time did not. Gender segregation has also been shown to be associated with the lack of upward progress of women and this is also related to working part time for women (Jacobs, 1999; Marshall et al, 1988). Men have gained advantages in occupational mobility over women by working in female dominated occupations and, in at least two studies, have the same chances as men in male dominated occupations (Heitmueller, 2004; Maume, 1999; Williams, 1992). 


\section{Data sources}

Starting with the position of women in 1980 from the Women and Employment Survey and 1981 Census this paper charts the change in occupations and occupational mobility of women by 2001 . Several data sources are used to construct this account.

The Women and Employment Survey was a cross-sectional representative sample of all women aged 16-59 in Great Britain. As well as the main cross-sectional interview, it asked women about their past employment history since leaving school and this contained retrospective records for 5320 women of their occupation and fertility histories up to 1980.

The National Child Development Study (NCDS), based on a census of babies born in a certain week of 1958 in Great Britain, contains information from up to 6 main interview waves up to 2000 , plus retrospective histories of employment and fertility about the women's and men's occupations. 5732 women's records and 5617 men's records were available for analysis from the Wave 6 data, at age 42. It was possible to recode the occupation categories in these two data sets to the same set of codes as the ones used in the 1980 Women and Employment Survey, described in more detail below.

The extent of occupational mobility will be examined using the 1980 WES data broken down into quasi cohorts as produced in Dex and Shaw (1986), and the 1958 birth cohort of women as far as its most recent contact at wave 6 (1999-2000). The WES cohorts analysed in Dex and Shaw (1986) were aged 44-58 and 26-36 in 1980, which translates into years of birth of 1922-1936 and 1943-1953 a gap, on average, of 21 years. These can be compared with the 1958 cohort of women born on average nearly 9 years later than the more recent of these WES cohorts.

\section{Occupational categories and recoding}

WES constructed its own set of 12 occupational categories for coding women's occupations although closely linked to SOC major codes (Table 1). At the time, the official SOC codes placed women's jobs into a rather small number of occupation groups. WES extended these to 12 in order to allow for an examination of more distinctions between women's jobs (Details of the contents of WES categories are presented in Appendix Table A2.) 
Table 1: Women and Employment Survey occupational groups

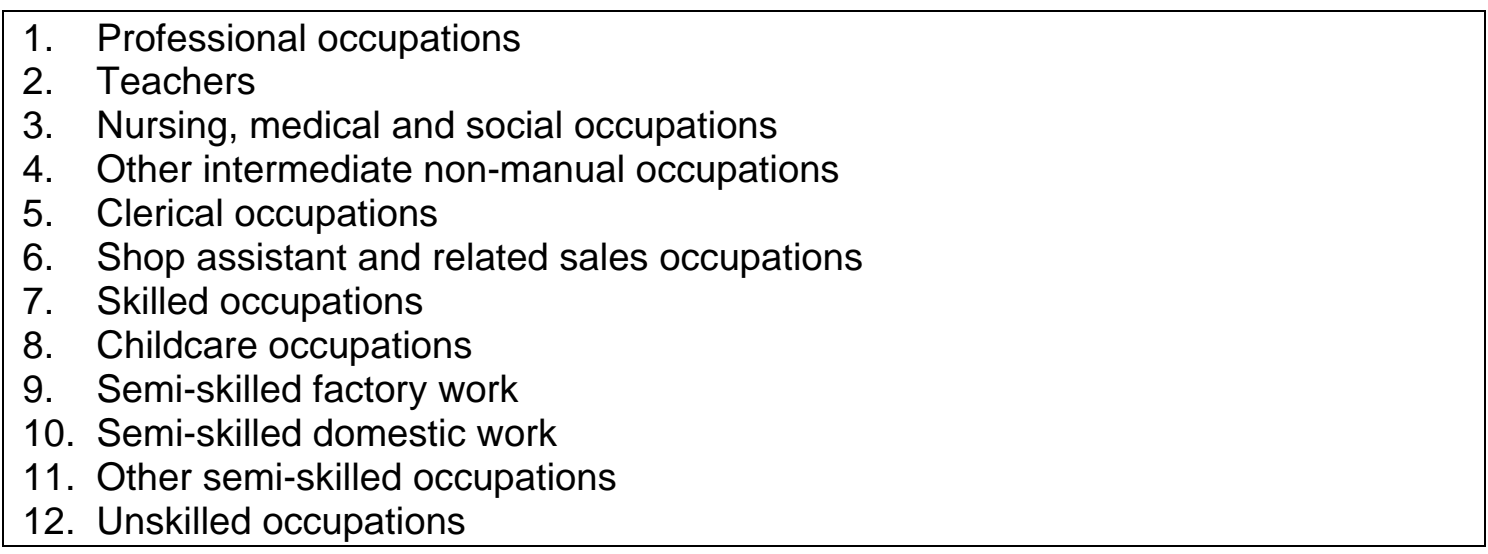

The WES scheme was applied to data on occupations from the NCDS to enable comparisons. As a check on the recoding, we compared the occupation distributions of the first ever job in NCDS, for employed women and men, with women aged approximately 22 in the WES data (born in 1958). We can only carry out this comparison in an approximate way using Martin and Roberts (1984) Table 10.13 (see Appendix Table A3). There is much reassuring correspondence between these occupational distributions. However, it is possible that the reclassification of NCDS occupations has placed slightly too many in the WES 'skilled' group and slightly too few in the 'semi-skilled factory' group.

\section{Vertical occupational mobility}

Clearly there is an approximate hierarchy in these WES occupation groups in Table 1. Dex (1987) examined the occupational profiles over women's lifetimes and ranked the occupations using the substitutability among some of these women's occupations. This led to grouping some of the lower level occupations in this list together since women clearly moved between shop assistant, semi-skilled domestic and other semi-skilled and child care occupations in a way that demonstrated they were substitute jobs for people with few if any qualifications or skills.

In this paper, we adopt the Dex rankings which collapse the 12 categories into eight and rank them in a clear order. This is mainly because we wish to draw some comparisons with Dex's earlier WES analyses of occupational mobility. The ranking on which we measure vertical occupational mobility is then as follows:
1. Professional
2. Teaching
3. Nursing
4. Intermediate non-manual work
5. Clerical
6. Skilled
7. Semi-skilled factory work
8. All other semi-skilled, shop assistant, child care and unskilled

The unskilled category was combined with the other semi-skilled groups because of its small sample size. Note that one 'non-manual' group, shop assistant, is ranked below two 'manual' groups, 'skilled', and 'semi-skilled factory work'. Joshi (1984) examined the hourly pay of each of these occupations and provided a ranking by hourly pay. This pay ranking of the 12 WES occupations is the same as Dex's 8 
groupings, with one exception. Ranking by hourly pay places childcare at the bottom, below other semi-skilled and unskilled categories. In this paper, also due to its relatively small size, childcare is combined with the other semi-skilled and unskilled jobs.

There is one other issue which arises in analysing vertical occupational mobility across cohorts. If occupational mobility occurs over the lifecourse, and we know it does, one can get different impressions of individuals' occupational progress by comparing them at different ages. So controlling for the ages or life stages will be important to the analysis. Our comparisons of what happens to women across childbirth controls for life stage, but not for age. Similarly, our comparisons of most recent jobs occur for NCDS women at age 42 (the most recent interview). For the WES cohorts whose data stop in 1980, those born from 1922-36 have most recent job information in 1980 at ages 44 to 58, and for those born 1943-53, most recent jobs apply to them at ages 27 to 37 . We need to consider these differences in drawing conclusions from our analyses.

\section{Occupational distributions}

An approximate comparison of the Census (1981) and General Household Survey (1980) distributions of employed women is displayed in Table 2 together with the Census (2001) results for employed women and men in 2001. The large shift up the occupational hierarchy by women is evident in these figures. The proportion of managers among employed women more than doubled from between 4 and 5.3 per cent in 1980/81 to 11.1 per cent in 2001. While women's representation was below that of men in managerial jobs at both times, the gap had narrowed substantially by 2001. Employed women also had a much larger percentage in professional and associate professional jobs by 2001 , increasing from $16-17$ per cent in $1980-81$ to 24.2 per cent in 2001, very close to the same percentage of men in such jobs in 2001 (25.6\%).

In the 1980 WES data, only a minority of women were classified as professional. One per cent of women in the 1981 Census were called professionals except that another 6 per cent were in teaching and 7 per cent in nursing or medical jobs which overlapped with the 'professional and associate professional' categories in the Census, 14 per cent in total. The same figure across all professional and associate professional jobs for employed women in NCDS at wave 6 was 19 per cent. 
Table 2: Occupational distributions of the employed

\begin{tabular}{|l|c|c|c|c|c|}
\hline Occupation categories & $\begin{array}{c}1981 \\
\text { Women } \\
\mathbf{1 6 - 5 9} \\
\text { (Census) } \\
\%\end{array}$ & $\begin{array}{c}1980 \\
\text { Women* } \\
\text { (GHS) } \\
\%\end{array}$ & $\begin{array}{c}1980 \\
\text { Men* } \\
\text { (GHS) } \\
\%\end{array}$ & $\begin{array}{c}\text { 2001 Women } \\
\mathbf{1 6 - 7 4} \\
\text { (England \& } \\
\text { Wales } \\
\text { Census) } \\
\%\end{array}$ & $\begin{array}{c}\text { 2001 Men } \\
16-74 \\
\text { (England \& } \\
\text { Wales } \\
\text { Census) } \\
\%\end{array}$ \\
\hline Managerial & 5.3 & 4 & 13 & 11.1 & 18.5 \\
\hline $\begin{array}{l}\text { Professional \& Associate } \\
\text { Professional }\end{array}$ & 17.2 & 16 & 19 & 24.2 & 25.6 \\
\hline Administrative and Secretarial & 30.2 & 33 & 6 & 22.7 & 5.4 \\
\hline Skilled Trades & 2.7 & 3 & 26 & 2.4 & 19.5 \\
\hline Personal Service & 20.6 & 23 & 3 & 12.7 & 2 \\
\hline Sales and Customer Service & 8.7 & 9 & 4 & 11.9 & 4.1 \\
\hline $\begin{array}{l}\text { Process plant \& machinery; } \\
\text { elementary trades }\end{array}$ & 6.3 & 11 & 25 & 15 & 24.9 \\
\hline Miscellaneous \& others & 4.7 & 1 & 3 & - & - \\
\hline Total \% & 100 & 100 & 100 & 100 & 100 \\
\hline Number & 987,888 & 3,354 & 8,024 & 10,836 thous & 12,791 thous \\
\hline
\end{tabular}

Source: Martin and Roberts (1984) Table 3.1 p.23.

\section{Occupational mobility}

A selection of ways of looking at occupational mobility are considered in this paper by varying the origin and destination points that are compared. We follow Dex's earlier focus on the occupations either side of the first childbirth. But we also consider mobility over the whole of the recorded occupational histories. The examination of a variety of lifespans of occupational mobility here is largely because we have some data on men's occupational mobility in NCDS which provides additional interest. However, it does not make sense to examine men's mobility across becoming a father since men do not usually change their jobs at this point in time. We examine first the childbirth span for women. In addition we examine the gaps out of employment mothers take around childbirth and the types of jobs they take on returning, both of which have also changed considerably in a way that is related to the occupational mobility that occurs at this lifestage.

\section{Either side of childbirth}

Dex's earlier analyses of women's occupational mobility across childbirth showed that there were large proportions of downward occupational mobility at this point in women's employment histories. However the extent varied by the origin occupation, measured as the last job before childbirth. Women in professional and teaching occupations (as a combined group because of the small number of professionals) all had significantly lower likelihood of downward occupational mobility than those whose pre-birth occupations were lower down the occupational hierarchy. The group with the largest chance of downward mobility were those in intermediate non-manual occupations prior to childbirth. Joshi and Newell (1987) found a similar pattern 
among the mothers and daughters of the 1946 birth cohort and suggested that those whose pre-birth job was one of the intermediate office jobs, such as the government or banks, would have firm- specific skills that were less transferable to other employers than those with more portable professional credentials.

In Figure 1 we present comparisons between 3 birth cohorts using WES and the NCDS cohort of women who have been through childbirth, by their pre-birth origin occupation. The mean age at motherhood for these women were found to be 24.9 years for those born in 1922 - 1936, 23.5 years for those born in $1943-1953$ and 25.1 years for those born in 1958.

Overall, downward mobility is less likely for those born in $1958(28.5 \%)$ compared to those born between 1943-1953 (34.8\%) and 1922-1936 (34.9\%). The figures for each cohort suggest, with the exception of the 'professional' and 'teachers' categories, that higher level occupations tend to have more stability across job transitions than occupations further down the hierarchy. Upward moves (see Appendix Table A4) are more plentiful from the lower level occupations than they are from the higher ones although its extent is not usually as great as the extent of downward mobility.

Figure 1: Percentage of women experiencing downward mobility when comparing their last job before childbirth and their first job after childbirth

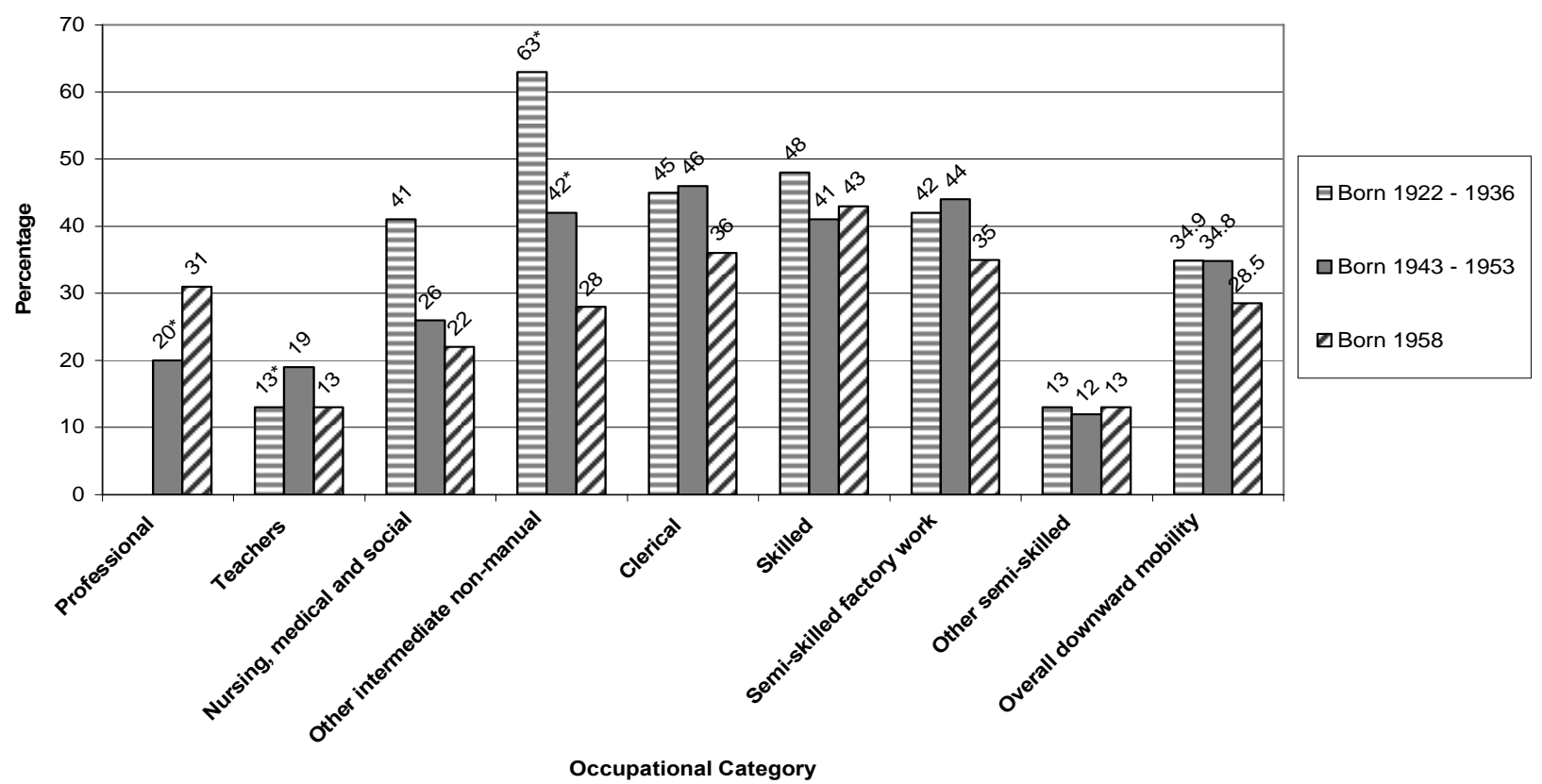

Sources: $1922-36$ cohort from WES data in Dex and Shaw (1986) regrouped. 1943-53 cohort from WES data in Dex and Shaw (1986) regrouped. 1958 cohort based on our analysis from NCDS data.

* indicates percentage based on small sample sizes.

Looking across these three cohorts at the top of the occupational hierarchy suggests that downward occupational mobility has declined over more recent cohorts at this life stage. For example, 19 per cent of teachers were downwardly mobile across childbirth when born in 1943-1953 compared with 13 per cent of the 1958 cohort of mothers. Women who had pre-birth jobs in nursing, medical or social occupations experienced downward occupational mobility in 41 per cent of cases if born in 1922- 
36, 26 per cent if born in 1943-53, and 22 per cent if born in 1958. The same trends over time can be seen across these 3 cohorts for mothers whose pre-birth jobs were intermediate non-manual (although based on very small numbers in the WES cohorts), skilled and other semi-skilled occupations. There were also declines in downward occupational mobility visible for women with pre-birth jobs in clerical and semi-skilled factory jobs by the time of the 1958 birth cohort, although not necessarily between the two earlier WES birth quasi cohorts.

The reduction in downward occupational mobility (Figure 1) could arise in two ways; either by the proportions staying in the same occupation across childbirth increasing, or by upward occupational mobility increasing at this point. On the whole, the reductions of downward occupational mobility across childbirth in the experiences of the 1958 cohort were predominantly improvements in the 'no change' percentages for pre-birth nursing, medical and social, intermediate non-manual, clerical and other semi-skilled occupations. For teachers, skilled and semi-skilled factory, the improvement arose from increases in upward occupational mobility, even to the extent of causing a decline in the percentages of women who stayed in the same occupation across childbirth.

These results suggest that there has been considerable change occurring over successive birth cohorts in the extent of women's occupational mobility across childbirth. Some of the change is consistent with the increased availability of maternity leave, giving women entitlements to return to the same job and occupation after childbirth. Also in some cases employers' have introduced new or explicit policies to retain women with family responsibilities, such as career break schemes, flexible working and job sharing, whose efficacy interacts with shorter breaks. The increased upward occupational mobility at this lifestage for some groups of women is probably due to an expansion of labour market opportunities for women that they faced on returning to work after childbirth.

\section{Durations of time out of work for childbirth}

Over time, the gap that women spend out of work giving birth to their first child has shortened considerably (Figure 2). Only 12.6 per cent of women born in 1922-1936 and 29.8 per cent of women born in 1943-1953, indicated that they spent less than one year out of the labour force for childbirth, compared to 44.7 per cent of women born in the 1958 cohort. 
Figure 2: Distribution of durations of time not working between first childbirth and first return to work

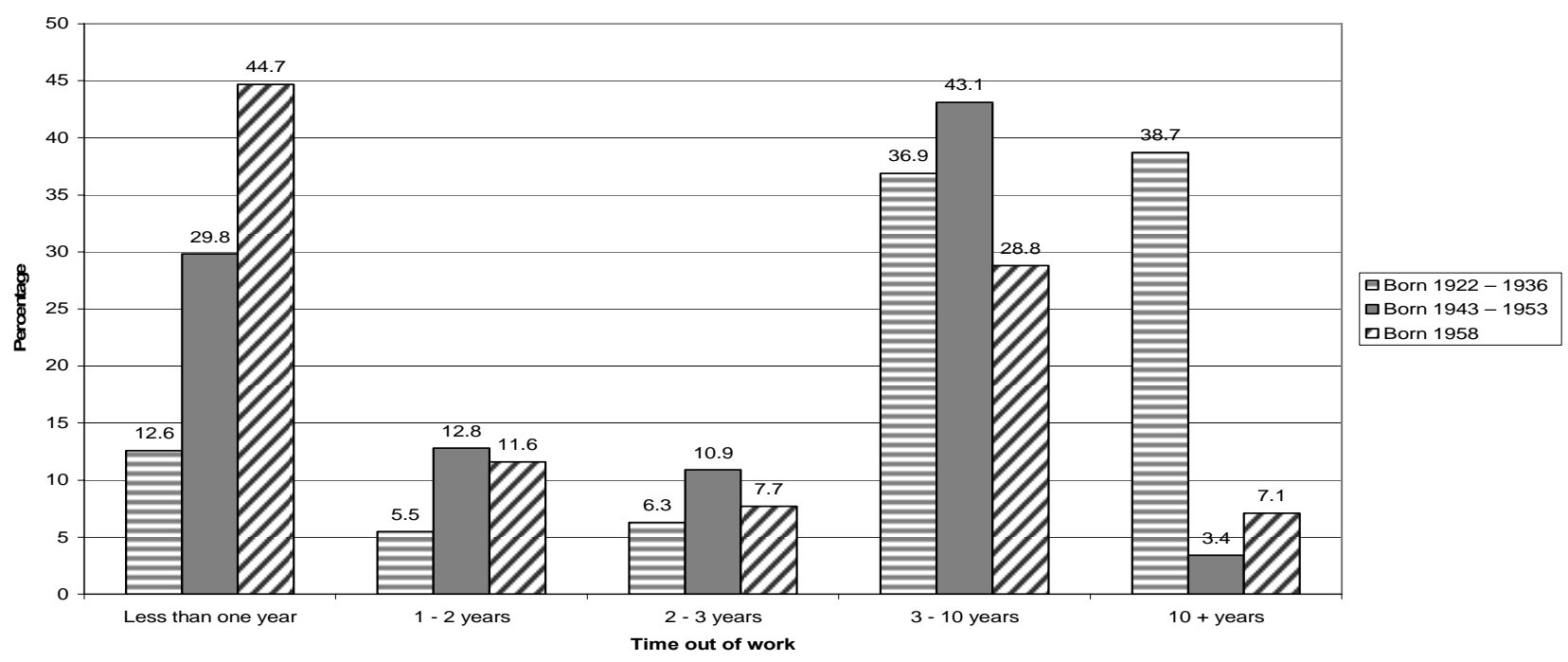

Sources: $1922-36$ cohort from WES data in Dex and Shaw (1986) regrouped. 1943-53 cohort from WES data in Dex and Shaw (1986) regrouped. Note: this group were at the most aged 27 years and therefore had not had a long time to return to work. The final distribution may look significantly different therefore. 1958 cohort based on our analysis from NCDS data. Maternity leavers are set to return in less than one year. Chart does not include any respondents whose employment ended prior to childbirth (556 cases in total)

Further evidence of this shortening gap out of paid work over childbirth was illustrated in Martin and Robert's (1984) analysis of WES women's work histories. Fourteen percent of WES women who had given birth and returned to work did so within 6 months. This proportion was lowest at 9 per cent in those who gave birth earliest from 1945-49, and progressively increasing as the age groups advanced to reach 17 per cent among those who gave birth from 1975-1979. The highest educated women were those who returned to work fastest after childbirth, but the differences by level of qualification were quite small in WES, ranging only from 14 to 17 per cent returning within 6 months of the first birth. The same trend of a declining gap from employment can be seen in successive birth cohorts of women (Figure 3). 
Figure 3: Years between first birth and next job at the median

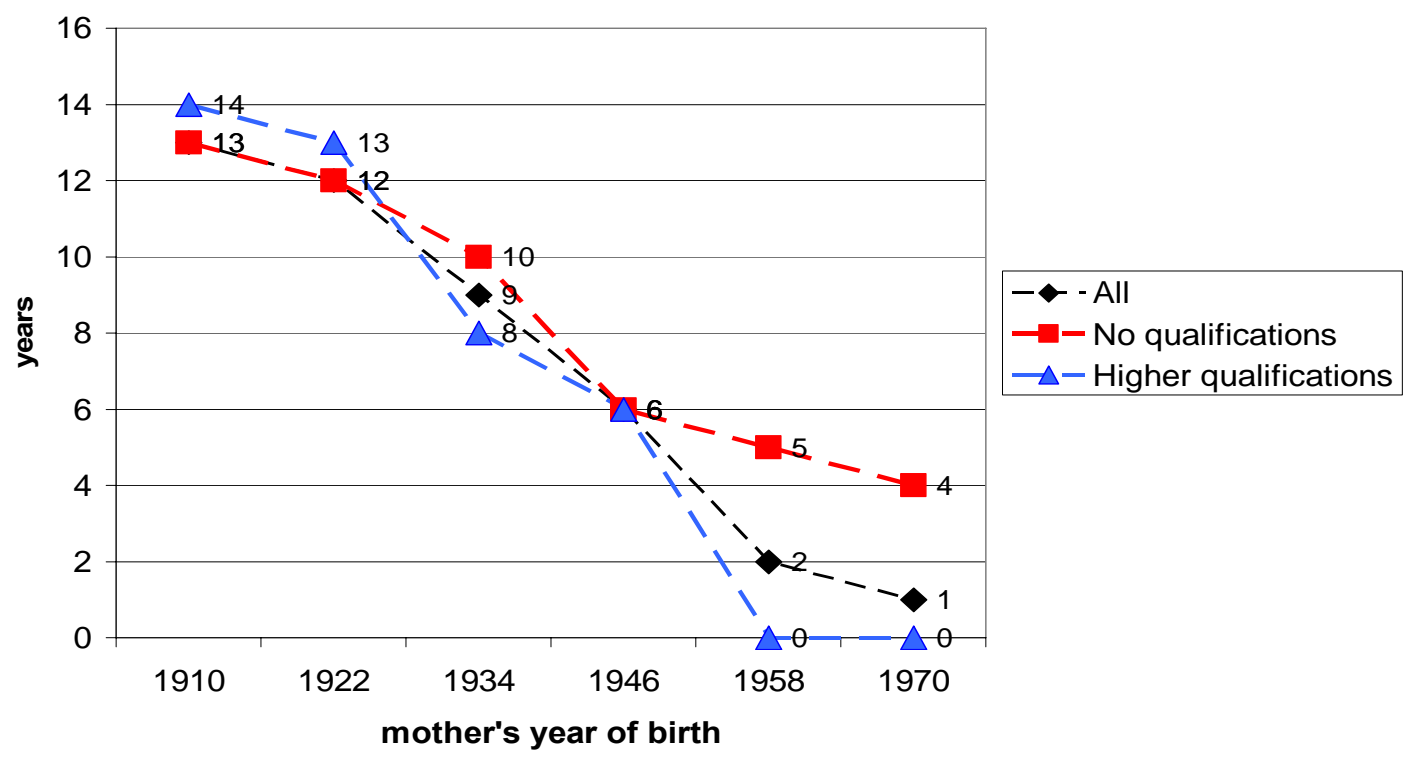

Sources: Joshi (1985), Joshi and Hinde (1993), Macran et al, (1996), Martin and Roberts (1984), Callender et al, (1997).

Of mothers born in 1946, 50 per cent of them had returned to work when their first child was 6 years old. Of mothers born in 1958, 50 per cent had returned by 2 years after the birth and of those born in 1970, 50 per cent had returned by one year after the birth. These figures varied in each cohort according to the level of qualification mothers held, especially since the 1958 cohort of mothers; more highly qualified mothers have made faster returns than those with lower levels of qualifications or no qualifications (Joshi (1985), Joshi and Hinde (1993), Macran et al, (1996), Martin and Roberts (1984), Callender et al, (1997)).

\section{Hours of return jobs}

The majority of first returns to employment after childbirth in WES were to part-time jobs, 68 per cent compared to 53 per cent of first returns in NCDS. This is one of the things better maternity leave provision has had a large impact on. Over successive cohorts, greater proportions of new mothers have been returning to full-time employment with the same employer after childbirth, as they have taken up maternity leave entitlements as shown in McRae's $(1991,1996)$ two surveys of mothers on maternity leave.

\section{Likelihood of downward occupational mobility across first childbirth}

Following Dex's $(1986,1987)$ earlier examination of the probabilities of downward occupational mobility of women in the WES data, we can examine how these probabilities have changed by the time NCDS mothers experienced their first childbirth (Table 3). We follow the earlier logistic model estimated on WES data reasonably closely in order to provide points of comparison. However some occupation groups are much larger in size in NCDS data and capable of being estimated separately rather than grouped together.

The results show a large measure of overlap in the determinants of downward occupational mobility for first time mothers in WES and NCDS. In both studies, 
returning to a part-time job after childbirth and spending longer out of employment are two factors that significantly increased the likelihood of downward occupational mobility occurring at this lifestage. Being in a teaching or nursing, medical and social occupation before childbirth decreased the likelihood of experiencing downward occupational mobility compared with someone in a semi-skilled factory occupation. An increased likelihood of downward occupational mobility was associated with a pre-birth occupation in intermediate non-manual work, clerical or skilled work.

Table 3: Correlates of women's downward occupational mobility - logistic

\begin{tabular}{|c|c|c|c|c|}
\hline \multicolumn{2}{|c|}{ Independent variables } & $\begin{array}{r}\text { WES } \\
2 \text { cohorts } \\
\text { Logit (a) }\end{array}$ & $\begin{array}{r}\text { NCDS } \\
\text { Women with } \\
\text { Birth } \\
\text { Model One (b) }\end{array}$ & $\begin{array}{r}\text { NCDS } \\
\text { Women with } \\
\text { Birth } \\
\text { Model Two (b) }\end{array}$ \\
\hline \multicolumn{2}{|c|}{ Returns part time } & $0.306(6.1)^{\star}$ & $2.11(0.09)^{\star}$ & $1.47(0.10)^{x}$ \\
\hline \multirow{6}{*}{$\begin{array}{l}\text { Duration to } \\
\text { return }\end{array}$} & years & $0.028(4.9)^{*}$ & $0.11(0.01)^{\star}$ & \\
\hline & 0 to 4 months & - & - & Reference \\
\hline & 5 to 12 months & - & - & $1.71(0.16)^{x}$ \\
\hline & 13 to 24 months & - & - & $1.70(0.16)^{*}$ \\
\hline & 25 to 60 months & - & - & $1.91(0.14)^{x}$ \\
\hline & $61+$ months & - & - & $2.11(0.14)^{x}$ \\
\hline \multirow{9}{*}{$\begin{array}{l}\text { Pre-birth } \\
\text { occupations }\end{array}$} & $\begin{array}{r}\text { Professional }+ \\
\text { teacher }\end{array}$ & $-0.263(2.5)^{\star}$ & - & - \\
\hline & Professional & - & $0.48(0.24)^{\star}$ & $0.56(0.26)^{x}$ \\
\hline & Teacher & - & $-0.79(0.28)^{\star}$ & $-0.85(0.28)^{*}$ \\
\hline & Nursing & $-0.128(1.5)$ & $-0.37(0.18)^{\star}$ & $-0.39(0.19)^{*}$ \\
\hline & $\begin{array}{r}\text { Intermediate non- } \\
\text { manual }\end{array}$ & $0.043(0.4)$ & $0.28(0.17)$ & $0.40(0.18)^{x}$ \\
\hline & Clerical & $0.030(0.6)$ & $0.18(0.13)$ & $0.14(0.13)$ \\
\hline & Skilled & $0.013(0.2)$ & $0.64(0.15)^{\star}$ & $0.59(0.16)^{x}$ \\
\hline & Other semi-skilled & Reference & Reference & Reference \\
\hline & All others & - & $-1.89(0.17)^{\star}$ & $-1.91(0.17)^{*}$ \\
\hline \multicolumn{2}{|l|}{ Constant } & $0.143(3.2)$ & $-2.47(0.13)^{\star}$ & $-3.14(0.15)^{x}$ \\
\hline \multicolumn{2}{|l|}{$\mathbf{N}$} & 679 & 4357 & 4357 \\
\hline \multicolumn{2}{|l|}{ Pseudo $\mathbf{R}^{2}$} & 0.130 & 0.248 & 0.279 \\
\hline \multicolumn{2}{|l|}{ Log likelihood } & -459.45 & -1969.371 & -1889.102 \\
\hline
\end{tabular}

(a) $t$ statistics in parenthesis

(b) Standard errors in parenthesis

The sizes of selected estimates of the effects on the probabilities of downward occupational mobility are displayed in Figures 4,5 and 6. This shows that the probability of downward occupational mobility has changed over time in a number of 
ways. All occupations have a reduced likelihood of downward mobility after childbirth in the 1958 cohort than in the WES data, by a relatively small amount, after controlling for other things (Figure 4). In the case of skilled workers, the reduction is much smaller than for other occupations.

Figure 4: Predicted probabilities of downward occupational mobility across first childbirth for WES and NCDS mothers by pre-birth occupation

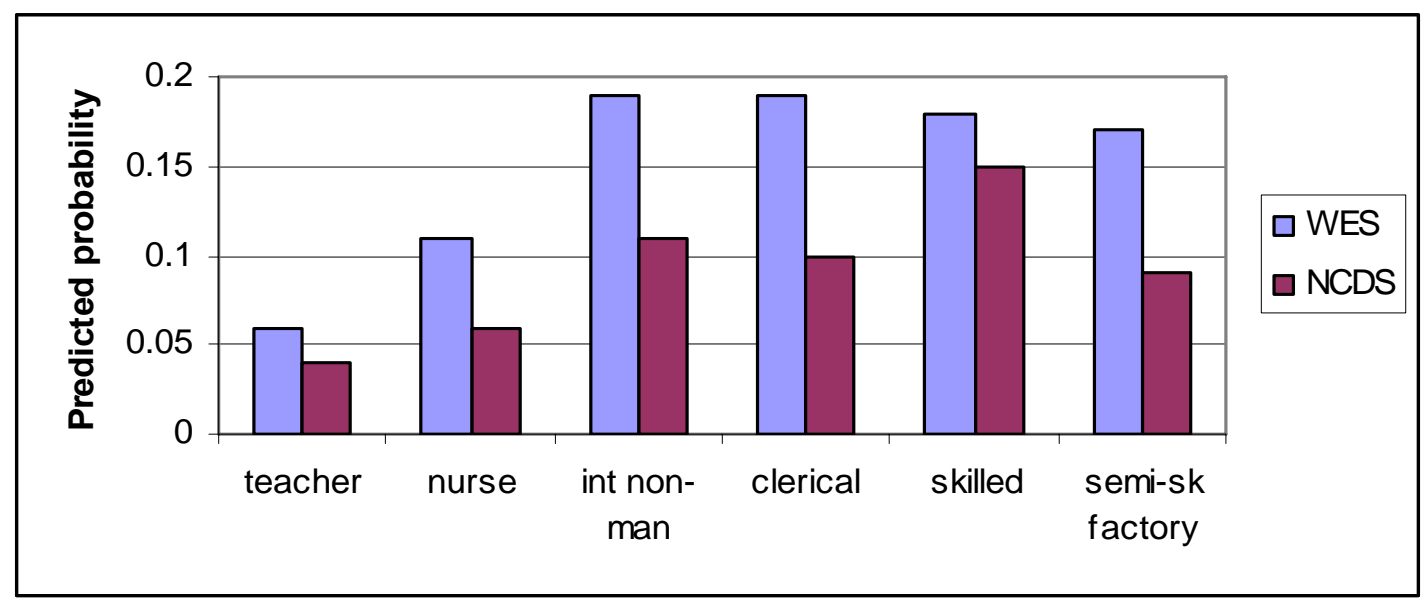

Based on a standard individual working part time, one year out of the labour market and Model one in Table 3 for NCDS.

Figure 5: Predicted probabilities of downward occupational mobility across first childbirth for WES and NCDS mothers by whether the first return was a full or part-time job

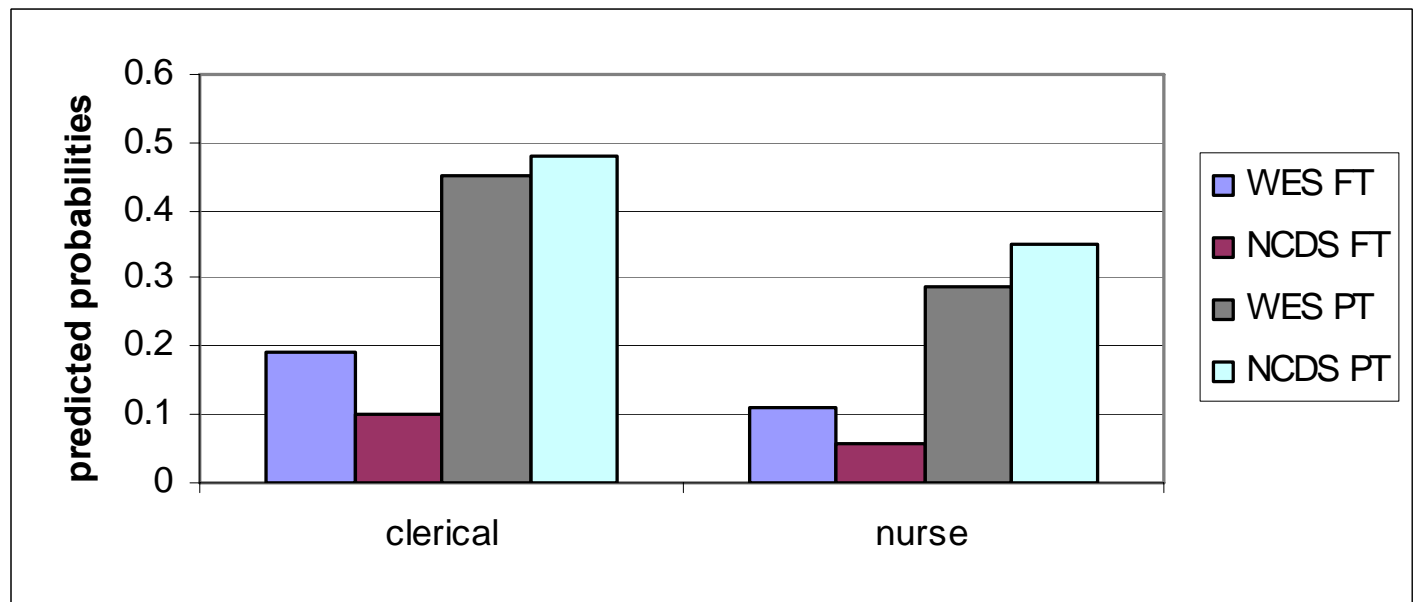

Based on a standard individual, one year out of the labour market and Model One in Table 3 for NCDS.

The likelihood of downward occupational mobility after childbirth has declined over time between the WES and NCDS cohorts if the mother returned to work full time (Figure 5). However, returning to work part time after childbirth is associated with a considerably higher chance of being downwardly mobile in NCDS compared with WES. The career penalty associated with working part time after childbirth appears to 
have increased over time, although, as reported earlier, there were fewer first returns to part-time employment among NCDS than among WES women.

Figure 6: Predicted probabilities of downward occupational mobility across first childbirth for WES and NCDS, teachers by years before first return to work

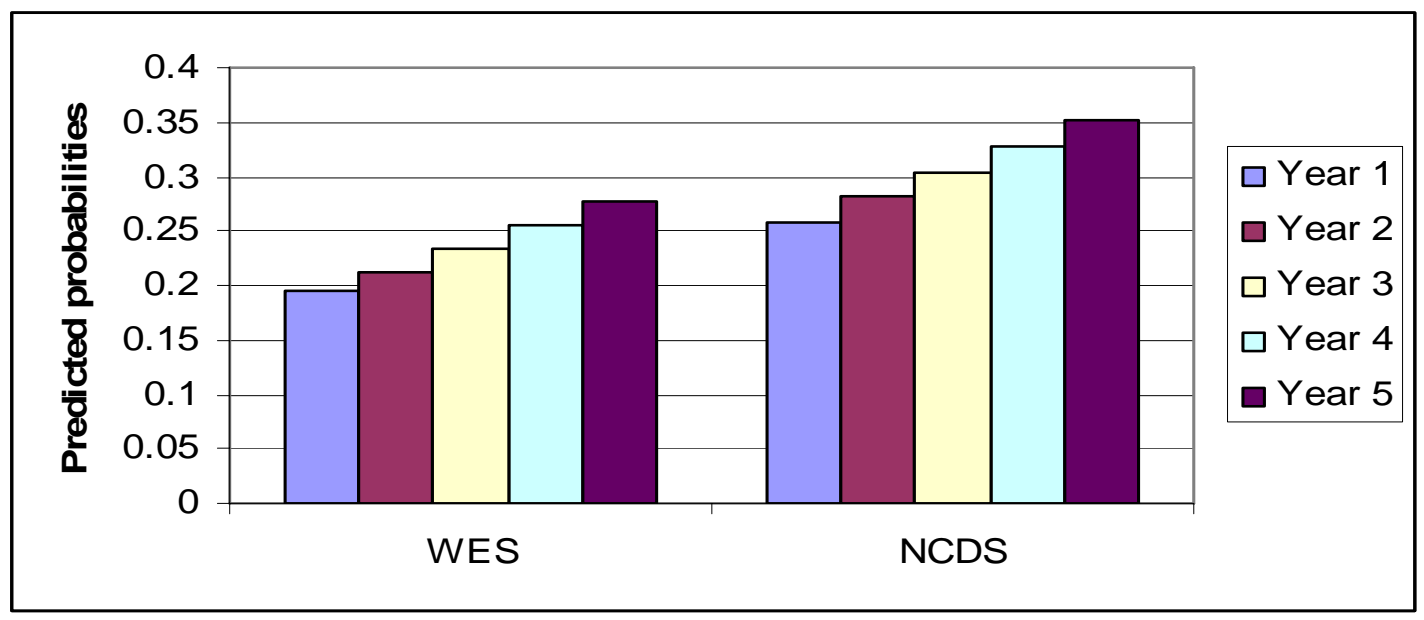

Based on standard individual working part time and a teacher before first birth and Model One in Table 3 for NCDS.

The penalty of increased downward occupational mobility associated with taking longer breaks from work over childbirth also increased, year on year, in NCDS compared with WES (Figure 6).

Overall, while there has been some improvement in women's prospects over successive cohorts, therefore, these improvements appear to be associated with behaviour that is more like those of men, having short or no breaks from employment across childbirth and returning to work full time as soon as possible. If women have longer breaks or return after childbirth to a part-time job, which has been the picture historically, the occupational penalties appear to have increased.

\section{Before childbirth to most recent jobs}

The first job after childbirth is not necessarily the end of the story of women's occupational mobility. In principle, they could regain their earlier status where it had been lost. They could also undergo further downward moves. Even those who maintained their occupational status across first childbirth might find it harder to maintain if they go on to have more children. We have made a further preliminary examination of downward mobility across cohorts by comparing last job before childbirth with most recent job (Table 4). As mentioned above, the most recent occupations refer to the older WES cohort when they were 44-58, the younger WES cohort when they were 27-37, and NCDS women when they were 42 years old. For this reason, we focus at this point only on the oldest WES cohort born in 1922-1936, aged 44-58 and the NCDS cohort born in 1958, aged 42.

The NCDS cohort experienced a far greater proportion of upward moves by their most recent job at age 42 than the earlier WES cohort. This is consistent with opportunities for women growing in extent and nature over the 1980s and 1990s in 
Great Britain. However, for some origin occupations, of the NCDS women, including nursing, medical, social, intermediate non-manual, skilled and semi-skilled factory, there are greater proportions of downward mobility in the most recent occupations at age 42 than was visible in the first return jobs after childbirth (see Tables 4 and 5 for NCDS). As mentioned above, a range of experiences can await women after they returned to work following the birth of their first child. These experiences can potentially have different effects on their vertical occupational mobility but need to be further analysed. This will have to wait for future analysis. Clearly it is not a story of mothers' onward and upward mobility or of unequivocally regaining lost occupational status after the first return to work after childbirth. 
Table 4: Occupation of last job before childbirth to most recent job

\begin{tabular}{|c|c|c|c|c|c|c|c|c|c|c|}
\hline \multirow{2}{*}{$\begin{array}{l}\text { Occupational } \\
\text { categories }\end{array}$} & \multicolumn{5}{|c|}{ Born 1922 - 1936} & \multicolumn{5}{|c|}{ Born 1958} \\
\hline & $\% \uparrow$ & Same & $\% \downarrow$ & Total (\%) & $\mathbf{N}$ & $\% \uparrow$ & Same & $\% \downarrow$ & Total (\%) & $\mathbf{N}$ \\
\hline Professional occupations & - & $(100)$ & - & 100 & 1 & - & 58 & 42 & 100 & 134 \\
\hline Teachers & - & $(80)$ & $(20)$ & 100 & 39 & 4 & 78 & 18 & 100 & 171 \\
\hline Nursing, medical and social occupations & 8 & 55 & 37 & 100 & 51 & 3 & 67 & 30 & 100 & 372 \\
\hline Other intermediate non-manual occupations & $(25)$ & $(19)$ & 56 & 100 & 16 & 12 & 51 & 37 & 100 & 425 \\
\hline Clerical occupations & 13 & 51 & 36 & 100 & 377 & 19 & 46 & 35 & 100 & 1537 \\
\hline Skilled occupations & 26 & 19 & 55 & 100 & 106 & 27 & 27 & 46 & 100 & 416 \\
\hline Semi-skilled factory work & 17 & 31 & 52 & 100 & 357 & 28 & 22 & 50 & 100 & 330 \\
\hline Other semi-skilled occupations & 39 & 46 & 15 & 100 & 302 & 43 & 49 & 8 & 100 & 875 \\
\hline Unskilled & $(64)$ & $(36)$ & - & 100 & 28 & 74 & 26 & - & 100 & 100 \\
\hline Total & 22 & 42 & 36 & 100 & 1277 & 27 & 41 & 32 & 100 & 4470 \\
\hline
\end{tabular}

Sources: $1922-36$ cohort from WES data in Dex and Shaw (1986) regrouped. 1958 cohort based on our analysis from NCDS data. 


\section{First job ever compared with most recent job}

The summary of occupational mobility from the first job ever to the most recent job for WES and NCDS women and NCDS men is displayed in Table 6. Among NCDS women with a child, 35 per cent had a higher occupation in their most recent job compared with 14 per cent of WES women with a child; 32 per cent of NCDS women were in the same occupations compared with 49 per cent of the WES sample and 33 per cent of NCDS women with a child were in lower occupations than they started out in compared with 37 per cent of WES women. Over the life course up to age 42, NCDS women who had children had experienced more occupational progression compared with the earlier WES sample of mixed ages.

For women without children in these two surveys the same findings are evident with 34 per cent of NCDS childless women being in a higher occupation in their last recent job compared with their first ever job, compared with 24 per cent of WES childless women. These figures confirm that over time women have been improving their rates of upward career mobility. However, this improvement has to be viewed against the greater downward mobility of women who have had children compared to the childless in WES and NCDS. Also NCDS men's overall upward mobility by age 42 , (38\%), is larger than NCDS women's (35\%), even childless women's (34\%) upward mobility. But these groups are not large.

Table 5: Occupation level of most recent job compared with first occupation in working life

\begin{tabular}{|l|r|r|r|r|r|r|}
\hline $\begin{array}{l}\text { Most recent } \\
\text { job } \\
\text { compared to } \\
\text { first job is: }\end{array}$ & $\begin{array}{r}\text { WES with } \\
\text { children* }\end{array}$ & $\begin{array}{r}\text { WES } \\
\text { without } \\
\text { children** }\end{array}$ & $\begin{array}{r}\text { NCDS all } \\
\text { women }\end{array}$ & $\begin{array}{r}\text { NCDS } \\
\text { with } \\
\text { child }\end{array}$ & $\begin{array}{r}\text { NCDS } \\
\text { without } \\
\text { child }\end{array}$ & $\begin{array}{r}\text { NCDS } \\
\text { men }\end{array}$ \\
\hline Higher & 14 & 24 & 35 & 35 & 34 & 38 \\
\hline Same & 49 & 60 & 35 & 32 & 45 & 42 \\
\hline Lower & 37 & 16 & 30 & 33 & 21 & 20 \\
\hline Total & 100 & 100 & 100 & 100 & 100 & 100 \\
\hline N & 3019 & 1316 & 6708 & 5004 & 1704 & 7000 \\
\hline
\end{tabular}

* Martins and Roberts (1984) Table 10.16 ** Martins and Roberts (1984) Table 10.14

\section{All occupational transitions by gender}

We can now investigate whether women's occupational transitions vary from those of men in the NCDS data. We consider all occupational transitions made by both men and women up to age 42 using the extended range of WES occupations in order to have more variation across men's jobs (Table 6).

When all transitions are included, the most stable occupation to occupation transitions are those between skilled jobs for men and teachers jobs for women, although nursing and clerical occupations also have high rates of transition to the same women's occupation. On the whole men are much less likely than women to move to the same occupation when they change jobs. The gender differences in 
some occupational transitions are particularly large at the high end of the occupational spectrum.

In the top three occupations, it is notable that men have greater percentages of downward occupational mobility than women although similarly small percentages of upward occupational mobility. At the bottom of the occupational hierarchy, men are more likely to have higher rates of upward mobility than women from many occupations (semi-skilled factory, sales, semi-skilled domestic, unskilled and even childcare) while men's extent of downward mobility is more equal to that of women's from the same origin occupations. One exception is skilled work where men are less likely to have downward and upward mobility than women, because they have such high rates of transitions to the same occupation. However, we need to remember at this point, as mentioned earlier, that the skilled category may have suffered from over-coding of semi-skilled factory jobs into the higher 'skilled' category which would lead to a small over-estimate of stability and a balancing small underestimate of downward occupational mobility.

There is slightly less downward occupational mobility from many origin occupations for childless as compared with all women (intermediate non-manual, clerical, skilled, sales and the semi-skilled categories), but the top occupation groups have either similar amounts of downward mobility for childless and all women or greater amounts for the childless. The experiences of childless women appear much more like those of all women in NCDS than they appear similar to men's experiences of occupational mobility.

These results are fairly surprising and run counter to many expectations on gender differences although they were also evident in Jacobs' research on men's employment histories. There is considerable occupational mobility in both women's and men's employment histories, more than would probably be expected. The overall picture gained from these comparisons of men's and women's occupational transitions over their lifecourse is that men in the 1958 cohort are not clearly doing better than women after they enter one of the higher level occupations, when all occupational moves are considered. Neither are childless women more similar to men in occupational mobility than they are to women with children. This is because certain occupations when held by men (e.g. skilled) exhibit certain patterns of occupational mobility, as do certain occupations held by women (e.g. clerical). It just goes to show it is worth examining the data, where this is possible, rather than making assumptions. These transitions give a picture of a very fluid labour market, and not one that is rigidly segmented, but one that has patterns of occupational mobility associated not only with the occupation but the gender of who holds most of the jobs. It is notable that NCDS men and women have lived through a long period of labour market restructuring from 1974 to 1998, as well as an expansion of opportunities for women. These things are likely to have made a substantial contribution to their occupational mobility, but also affecting labour market structures. 
Table 6: All occupational transitions (NCDS) (per cents)

\begin{tabular}{|c|c|c|c|c|c|c|c|c|c|c|c|c|c|c|c|}
\hline \multirow{2}{*}{ Occupation category } & \multicolumn{5}{|c|}{ ALL NCDS women up to $42 \mathrm{yrs}$ old } & \multicolumn{5}{|c|}{ ALL NCDS men up to 42 yrs old } & \multicolumn{5}{|c|}{ All childless women in NCDS up to 42 yrs old } \\
\hline & $\% \uparrow$ & Same & $\% \downarrow$ & $\begin{array}{c}\text { Row } \\
\%\end{array}$ & Total & $\% \uparrow$ & Same & $\% \downarrow$ & $\begin{array}{c}\text { Row } \\
\%\end{array}$ & Total & $\% \uparrow$ & Same & $\% \downarrow$ & $\begin{array}{c}\text { Row } \\
\%\end{array}$ & Total \\
\hline Professional & - & 53 & 47 & 100 & 770 & & 48 & 52 & 100 & 1615 & * & 55 & 45 & 100 & 213 \\
\hline Teachers & 2 & 73 & 22 & 100 & 865 & 4 & 56 & 40 & 100 & 257 & 5 & 67 & 28 & 100 & 195 \\
\hline $\begin{array}{l}\text { Nursing, medical and } \\
\text { social }\end{array}$ & 3 & 65 & 32 & 100 & 2483 & 8 & 49 & 43 & 100 & 301 & 4 & 64 & 33 & 100 & 428 \\
\hline $\begin{array}{l}\text { Other intermediate } \\
\text { non-manual }\end{array}$ & 10 & 42 & 48 & 100 & 2812 & 8 & 59 & 33 & 100 & 4735 & 13 & 48 & 39 & 100 & 709 \\
\hline Clerical & 15 & 61 & 24 & 100 & 9281 & 26 & 48 & 26 & 100 & 2431 & 20 & 62 & 18 & 100 & 1791 \\
\hline Skilled & 23 & 41 & 36 & 100 & 2994 & 11 & 67 & 22 & 100 & 12393 & 31 & 38 & 31 & 100 & 460 \\
\hline $\begin{array}{l}\text { Semi-skilled factory } \\
\text { work }\end{array}$ & 30 & 31 & 29 & 100 & 1722 & 46 & 25 & 29 & 100 & 2131 & 43 & 29 & 28 & 100 & 216 \\
\hline $\begin{array}{l}\text { Shop assistant and } \\
\text { related sales }\end{array}$ & 44 & 35 & 21 & 100 & 3564 & 54 & 31 & 15 & 100 & 1527 & 53 & 31 & 16 & 100 & 510 \\
\hline $\begin{array}{l}\text { Semi-skilled domestic } \\
\text { work }\end{array}$ & 52 & 33 & 15 & 100 & 2088 & 56 & 19 & 25 & 100 & 611 & 65 & 25 & 10 & 100 & 252 \\
\hline Other semi-skilled & 66 & 23 & 11 & 100 & 1604 & 57 & 32 & 11 & 100 & 2928 & 68 & 26 & 6 & 100 & 237 \\
\hline Unskilled & 67 & 27 & 6 & 100 & 1301 & 81 & 21 & - & 100 & 2938 & 72 & 23 & 5 & 100 & 117 \\
\hline Childcare & 72 & 28 & - & 100 & 988 & 97 & 3 & - & 100 & 118 & 79 & 21 & * & 100 & 205 \\
\hline All & 27 & 47 & 26 & 100 & 30472 & 27 & 50 & 23 & 100 & 31985 & 29 & 48 & 23 & 100 & 5333 \\
\hline
\end{tabular}

Source: All occupational transitions including those who only ever had one occupation. 


\section{Conclusions}

Dex's analysis of the 1980 WES occupation data was used to suggest a modification to the segmented labour market theories current at the time. This paper reviews where we have got to 25 years later, on women's place in the labour market and the workings of the labour market in general.

The Women and Employment Survey was a major landmark in showing that by 1980 , women were successfully combining motherhood with employment. It came as something of a surprise to learn from the employment histories that as many as 90 per cent of mothers eventually returned to the labour market after a gap for childbirth. It was also evident, even then, that successive (quasi) cohorts were bringing forward this return and closing the gap.

These changes were seen in 1980, shortly after the UK had embraced statutory provisions for mothers' employment rights for maternity and legislation about discrimination. The WES data suggested that women's behaviour had been changing even in advance of the statutory framework.

It was less surprising to find that women suffered downward occupational mobility at this lifestage of giving birth, although some managed to regain their earlier status. This downward occupational mobility varied by occupation but was at higher rates with longer durations out of employment for childbirth and where mothers returned to a part-time job. This was an aspect of women's employment where the new right to return to the same job had not had time to affect many lives.

The intervening 25 years show much continuity with these earlier developments. Women have continued to return to work after childbirth at faster rates. More of them have returned after childbirth to the same jobs, same employers and same full-time hours of work. These changes have undoubtedly been assisted by the imbedding and enhancement over 25 years of statutory maternity leave arrangements, and the realization that human resource management could be relevant for women, particularly the new cohorts of qualified womanpower.

In this paper we have been able to follow women's progress up to 2000 through the experiences of women born in 1958. Through this lens we have seen that downward occupational mobility over first childbirth has declined compared with earlier generations in WES. However, there is still additional downward occupational mobility following the first return after first childbirth to most recent jobs for some of these women. We were unable to identify its causes at this point.

The 1958 cohort of women also demonstrates that the penalty to their occupational status of taking a part-time job on returning to work after (first) childbirth, or spending a few years out of employment have increased compared with the WES generations. One other important finding from the analysis of NCDS men's occupational mobility is that men too experience at least as much downward occupational mobility as women over their careers up to age 42, although they don't on the whole drop into part-time jobs. Also men's downward occupational mobility is unlikely to be concentrated around the arrival of children. Where women worked in the less gender segregated parts of the British labour market of the 1980's and 1990's, and maintained employment profiles hitherto characteristic of men, they were able to maintain occupational status and progression and keep pace with the men. Where they wanted to deviate and spend more time being mothers, the penalties appear to have been greater. Clearly this examination of mobility between occupational categories is 
only part of the story. There is within-occupation progression and wage rate mobility which should be linked with occupational category changes.

An examination of more recent cohorts will extend the story further. Some of these later cohorts have been having their children under the more recent legislation requiring equal treatment for part-time employees and offering rights for parents to request flexibility from employers. These recent policy developments may help to break the link between downward occupational mobility and part-time jobs. We will have to see. 


\section{References}

Blackwell, L. (2001) 'Women's work in UK official statistics and in the 1980 reclassification of occupations', Journal of Royal Statistical Society, 164(2): 307-25.

Blau, P.M. and Duncan, O.D. (1967) The American occupational structure, New York: Wiley and Sons.

Booth, A. and Francesconi, M. (1999) Job mobility in 1990s Britain: does gender matter? Institute for Social and Economic Research Working Paper, Colchester: University of Essex.

Callender, C., Millward, N., Lissenburgh, S. and Forth, J. (1997) Maternity rights and benefits in Britain, Social Security Research Report 67, London: The Stationery Office.

Dex, S. (1996) British and American Women at work, Basingstoke: Macmillan.

Dex, S. (1987) Women's occupational mobility, Basingstoke: Macmillan.

Dolton, P. and Silles, M. (2001) Over-education in the graduate labour market: some evidence from alumni data, Centre for the Economics of Education Working Paper, London: Institute of Education and LSE.

Elias, P. and Main, B. (1982) Women's working lives: evidence from the National Training Survey, Coventry: Institute for Employment Research, University of Warwick.

Goldthorpe, J. (1987) Social mobility and class structure in modern Britain, Oxford: Clarendon Press.

Heitmueller, A. (2004) 'Job mobility in Britain: are the Scots different? Evidence from the BHPS', Scottish Journal of Political Economy, 51(3).

Jacobs, S. (1999) 'Trends in women's career patterns and in gender occupational mobility in Britain', Gender, Work and Organization, 6(1):.32-46.

Joshi, H. (1984) Women's participation in paid work: further analysis of the Women and Employment Survey, Department for Employment, Research Paper, No.45. London: HMSO.

Joshi, H. and Newell, M-L. (1987) 'Job downgrading after childbirth'. In M. Uncles (ed.) London papers in regional science 18. Longitudinal data analysis: Methods and applications, London: Pion.

Joshi, H. E. (1985) 'Motherhood and employment: change and continuity in post-war Britain'. In Measuring Socio- Demographic Change, Occasional Paper No 34, London: OPCS, 70-87.

Joshi, H. and Hinde, P. (1993) 'Employment after childbearing: cohort study evidence'. European Sociological Review, 9: 203-227.

Leontaridi, M.R. (1998) 'Segmented labour markets: theory and evidence', Journal of Economic Surveys, 12: 63-101. 
Marshall,G et al (1988) Social class in modern Britain, London: Hutchinson.

Martin, J. and Roberts, C. (1984) Women and employment: a lifetime perspective, London: Department of Employment and OPCS.

Macran, S., Joshi, H.E. and Dex, S. (1996) 'Employment after childbearing: a survival analysis', Work, Employment and Society, 10(2): 273-296.

Maume, D. (1999) 'Glass ceilings and glass escalators: occupational segregation and race and sex differences in managerial promotions', Work and Occupations, 26: 483509.

McRae, S. (1991) Maternity rights In Britain, London: Policy Studies Institute.

McRae, S. (1996) Maternity rights In Britain, London: Policy Studies Institute.

Payne, G. and Abbott, P. (eds) (1990) The social mobility of women, London: Falmer.

Rosenfeld, R.A. (1979) 'Women's occupational careers, individual and structural explanations'. Sociology of Work and Occupations, 6(3): 283-311

Sousa-Poza, A. (2004) 'Is the Swiss labor market segmented?' Labour, 18(1): 13161.

Stewart, M. and Greenhalgh, C. (1984) 'Work history patterns and the occupational attainment of women', Economic Journal, 94(375): 493-519.

Stewart, M.B. and Swaffield, J.K. (1999) 'Low pay dynamics and transition probabilities', Economica, 66: 23-42.

Theodossiou, I. (1995) 'Wage determination for career and non-career workers in the UK: Is there labour market segmentation?' Economica, 62: 195-211.

Williams, C.L. (1992) 'The glass escalator: hidden advantages for men in the "female" professions', Social Problems, 39: 253-67. 


\section{Appendix}

Table A1: Sex discrimination legislation in Britain

\section{Sex Discrimination Act 1975}

The Sex Discrimination Act 1975 makes sex discrimination unlawful in employment, vocational training and education. This legislation prohibits any direct or indirect discrimination, victimisation and harassment on the grounds of sex and has been updated to also prohibit any discrimination on the grounds of pregnancy or maternity leave. In employment and vocational training, this legislation also prohibits any discrimination against a person due to their marital or partnership status (updated from December 2005 to include a civil partner).

\section{Equal Pay Act 1970}

The Equal Pay Act 1970 was passed to prohibit employers to discriminate between men and women who are doing the same work or similar/equivalent work which is of equal value. This covers the salary and other terms and conditions such as bonus payments, holidays and sick leave. 
Table A2: Women's employment survey occupational categories

\begin{tabular}{|c|c|}
\hline 1 & $\begin{array}{l}\text { Professional occupations } \\
\text { Barristers, solicitors, chartered and certified accountants, university teachers, doctors, } \\
\text { dentists, physicists, chemists, social scientists, pharmacists, dispensing opticians, qualified } \\
\text { engineers, architects, town planners, civil servants - Assistant Secretary level and above. }\end{array}$ \\
\hline 2 & $\begin{array}{l}\text { Teachers } \\
\text { Primary and secondary school teachers, teachers in further and higher education (not } \\
\text { universities), head teachers, nursery teachers, vocational and industrial trainers. }\end{array}$ \\
\hline 3 & $\begin{array}{l}\text { Nursing, medical and social occupations } \\
\text { SRN, SEN, nursing auxiliary, midwife, health visitor, children's nurse, } \\
\text { matron/superintendent, dental nurse, dietician, radiographer, physiotherapist, chiropodist, } \\
\text { dispenser, medical technician, houseparent's, welfare occupations (including social } \\
\text { workers), occupational therapist. }\end{array}$ \\
\hline 4 & $\begin{array}{l}\text { Other intermediate non-manual occupations } \\
\text { Civil Servants - Executive Officer to Senior Principal level and equivalent in central and } \\
\text { local government, computer programmer, systems analyst, O \& M analyst, librarian, } \\
\text { surveyor, personnel officer, managers, self-employed farmers, shopkeepers, publicans, } \\
\text { hoteliers, buyers, company secretary, author, writer, journalist, artist, designer, window } \\
\text { dresser, entertainer, musician, actress. }\end{array}$ \\
\hline 5 & $\begin{array}{l}\text { Clerical occupations } \\
\text { Typist, secretary, shorthand writer, clerk, receptionist, personal assistant, cashier, (not } \\
\text { retail), telephonist receptionist, office machine operator, computer operator, punch card } \\
\text { operator, data processor, draughtswoman, tracer, market research interviewer, debt } \\
\text { collector. }\end{array}$ \\
\hline 6 & $\begin{array}{l}\text { Shop assistant and related sales occupations } \\
\text { People selling goods in wholesale or retail establishments, cashiers, in retail shops, check } \\
\text { out and cash and wrap operators, petrol pump attendant, sales representative, } \\
\text { demonstrator, theatre/cinema usherette, programme seller, insurance agent. }\end{array}$ \\
\hline 7 & $\begin{array}{l}\text { Skilled occupations } \\
\text { Hairdresser, manicurist, beautician, make-up artist, cook, domestic and institution } \\
\text { housekeeper, nursery nurse, travel stewardess, ambulance woman, van driver and } \\
\text { deliveries, baker, weaver, knitter, mender, darner, tailoress and dressmaker (whole } \\
\text { garment), clothing cutter, milliner, upholsterer, bookbinder, precision instrument maker and } \\
\text { repairer, instrument assemblers, laboratory assistant, driving instructor, policewoman. }\end{array}$ \\
\hline 8 & $\begin{array}{l}\text { Childcare occupations } \\
\text { Childminder, school meals and playgroup supervisor or leader, nanny, au pair, people } \\
\text { doing housework in addition to childcare (NB exclude nursing and teaching). }\end{array}$ \\
\hline 9 & $\begin{array}{l}\text { Semi-skilled factory work } \\
\text { Assembler, packer, labeller, grader, sorter, inspector, machinist, machine operator, paper } \\
\text { wrapping, filling or sealing containers, spinner, doubler, twister, winder, reeler. }\end{array}$ \\
\hline 10 & $\begin{array}{l}\text { Semi-skilled domestic work } \\
\text { Waitress, barmaid, canteen assistant, people serving food at tables or counters, serving } \\
\text { school meals, home help, care attendant, ward orderly, housemaid, domestic worker. }\end{array}$ \\
\hline 11 & $\begin{array}{l}\text { Other semi-skilled occupations } \\
\text { Agricultural worker, groom, kennel maid, shelf filler, bus conductress, ticket collector, post } \\
\text { woman, mail sorter, laundress, dry cleaner, presser, mail order and catalogue agent, market } \\
\text { and street trader, collector saleswoman, traffic warden, telephone operator, photographer. }\end{array}$ \\
\hline 12 & $\begin{array}{l}\text { Unskilled occupations } \\
\text { Cleaner, charwoman, kitchen hand, labourer, messenger. }\end{array}$ \\
\hline
\end{tabular}


Table A3: First occupations

\begin{tabular}{|l|c|c|c|c|}
\hline Occupation categories & $\begin{array}{c}\text { WES } \\
\mathbf{2 0 - 2 4}\end{array}$ & $\begin{array}{c}\text { WES } \\
\mathbf{2 5 - 2 9}\end{array}$ & $\begin{array}{c}\text { NCDS } \\
\text { Women }\end{array}$ & $\begin{array}{c}\text { NCDS } \\
\text { Men }\end{array}$ \\
\hline Professional occupations & - & 2 & 1.7 & 4.8 \\
\hline Teacher & 2 & 6 & 2.8 & 1 \\
\hline $\begin{array}{l}\text { Nursing, medical and social } \\
\text { occupations }\end{array}$ & 4 & 5 & 5.7 & 0.5 \\
\hline $\begin{array}{l}\text { Other Intermediate non-manual } \\
\text { occupations }\end{array}$ & 2 & 3 & 5.1 & 9.3 \\
\hline Clerical occupations & 39 & 39 & 38.9 & 9.5 \\
\hline Skilled occupations & 10 & 9 & 12.3 & 43.4 \\
\hline $\begin{array}{l}\text { Shop assistant and related sales } \\
\text { occupations }\end{array}$ & 17 & 16 & 14.1 & 5.1 \\
\hline Childcare occupations & 1 & 1 & 2.4 & 0.2 \\
\hline Semi-skilled factory work & 15 & 15 & 6.1 & 7.3 \\
\hline Semi-skilled domestic & 4 & 2 & 4.2 & 1.8 \\
\hline Other Semi-skilled & 4 & 2 & 4.8 & 10.1 \\
\hline Unskilled & 2 & 0 & 1.9 & 6.9 \\
\hline Total & 100 & 100 & 100 & 100 \\
\hline N & 560 & 679 & 6708 & 7000 \\
\hline
\end{tabular}

Source: Martin and Roberts (1984), Table 10.13. 
Table A4: Women's last job before and first job after childbirth

\begin{tabular}{|c|c|c|c|c|c|c|c|c|c|c|c|c|c|c|c|}
\hline \multirow{2}{*}{$\begin{array}{l}\text { Occupational } \\
\text { Categories }\end{array}$} & \multicolumn{5}{|c|}{ Born 1922 - 1936} & \multicolumn{5}{|c|}{ Born 1943 - 1953} & \multicolumn{5}{|c|}{ Born 1958} \\
\hline & $\% \uparrow$ & Same & $\% \downarrow$ & $\begin{array}{r}\text { Total } \\
(\%)\end{array}$ & $\mathbf{N}$ & $\% \uparrow$ & Same & $\% \downarrow$ & $\begin{array}{r}\text { Total } \\
(\%)\end{array}$ & $\mathbf{N}$ & $\% \uparrow$ & Same & $\% \downarrow$ & $\begin{array}{r}\text { Total } \\
(\%)\end{array}$ & $\mathbf{N}$ \\
\hline Professional & $(100)$ & - & - & 100 & 1 & - & (80) & $(20)$ & 100 & 5 & - & 69 & 31 & 100 & 132 \\
\hline Teachers & - & (87) & (13) & 100 & 39 & - & 83 & 19 & 100 & 40 & 3 & 84 & 13 & 100 & 169 \\
\hline $\begin{array}{l}\text { Nursing, medical } \\
\text { and social }\end{array}$ & 6 & 53 & 41 & 100 & 51 & 2 & 72 & 26 & 100 & 57 & 1 & 77 & 22 & 100 & 366 \\
\hline $\begin{array}{l}\text { Other intermediate } \\
\text { non-manual }\end{array}$ & (6) & (31) & $(63)$ & 100 & 16 & (8) & (48) & $(42)$ & 100 & 23 & 7 & 65 & 28 & 100 & 424 \\
\hline Clerical & 6 & 49 & 45 & 100 & 377 & 5 & 49 & 46 & 100 & 288 & 8 & 56 & 36 & 100 & 1522 \\
\hline Skilled & 16 & 36 & 48 & 100 & 106 & 9 & 50 & 41 & 100 & 76 & 14 & 43 & 43 & 100 & 517 \\
\hline $\begin{array}{l}\text { Semi-skilled factory } \\
\text { work }\end{array}$ & 8 & 50 & 42 & 100 & 357 & 5 & 51 & 44 & 100 & 173 & 31 & 34 & 35 & 100 & 325 \\
\hline Other semi-skilled & 26 & 61 & 13 & 100 & 302 & 30 & 58 & 12 & 100 & 176 & 28 & 59 & 13 & 100 & 860 \\
\hline Unskilled & (63) & (37) & - & 100 & 27 & 33 & (67) & - & 100 & 6 & 44 & 56 & - & 100 & 100 \\
\hline Total & 13.2 & 51.9 & 34.9 & 100 & 1276 & 10.5 & 54.7 & 34.8 & 100 & 844 & 14.0 & 57.5 & 28.5 & 100 & 4415 \\
\hline
\end{tabular}

Sources: $1922-36$ cohort from WES data in Dex and Shaw (1986) regrouped. 1943-53 cohort from WES data in Dex and Shaw (1986) regrouped.

1958 cohort based on our analysis from NCDS data 